\title{
Association of Vitamin D and its Receptor (VDR) Gene Single Nucleotide Polymorphism (ApaI and TaqI) with Risk of Psoriasis
}

\author{
Muhammad Irfan Shereen ${ }^{1}$, Mohsin Shah ${ }^{1}$, Sami Siraj ${ }^{2}$, \\ Mohsin $\mathrm{Ali}^{2}$, Muhammad Adnan Shereen ${ }^{3}$ and Abeer Kazmi ${ }^{* 3,4}$
}

\begin{abstract}
Introduction: Psoriasis is one of the skin related inflammatory diseases that affects a low percentage of population around the globe. Vitamin D through Vitamin D Receptor (VDR) also regulates the function of white blood cells in psoriasis. Mutations in VDR gene have shown abnormalities in immune responses like psoriatic arthritis. To determine the possible association between Vitamin D Receptor (ApaI and TaqI) gene polymorphism and psoriasis, a case-control study was designed and conducted at the Institute of Basic Medical Sciences (IBMS), Khyber Medical University (KMU) Peshawar and health units of Peshawar.

Method: This multi-centre study included 220 samples (110 cases of psoriatic disease and 110 healthy controls). DNA was extracted using modified salting out protocol. VDR gene polymorphisms (TaqI and ApaI) were genotyped using amplification refractory mutation system using polymerase chain reaction (ARMSPCR) method. Results were statistically analyzed.

Result: Our study showed significant association between VDR gene (TaqI, ApaI) polymorphisms and psoriasis with p-value of 0.009 (0.0019 and 0.0162) and odds ratios (95\% confidence interval) for psoriasis of CC vs CT (TaqI) and AA vs AC (ApaI) were 2.963 (95\% CI: 1.508-5.743) and 2.293 (95\% CI:1.22-4.246) respectively. Conclusion: Findings indicate that VDR gene polymorphisms (TaqI, ApaI) are significantly associated with onset and progression of psoriasis, and mutations in these loci are risk factors for development of psoriasis.
\end{abstract}

Key words: Psoriasis, VDR polymorphism, TaqI, ApaI, South Asia, Pakistan

How to cite this article: Shereen MI, Shah M, Siraj S, Ali M, Shereen MA, Kazmi A. Association of vitamin D and its receptor (VDR) gene single nucleotide polymorphism (ApaI and TaqI) with risk of psoriasis. Ann Jinnah Sindh Med Uni 2020; 6(2):37-43

DOI: https://doi.org/10.46663/ajsmu.v6i2.37-43

\section{INTRODUCTION}

Psoriasis is a type of chronic skin inflammatory disorder which affects $1-3 \%$ of total world population and adversely affects quality of life. It is an auto-immune type of disorder. Symptoms include rapid growth of epidermal cells accompanied by inflammation of underlying dermal layer ${ }^{1}$. The word psoriasis was derived from Greek word "Psora" meaning "to be itchy"2. It is one of the two familiar immune-mediated skin inflammatory diseases. The other one is atopic dermatitis $^{3}$, characterized by skin inflammation and other symptoms including initial small and raised red

Department of Physiology / Department of Pharmacology ${ }^{2}$, Institute of Basic Medical Sciences, Khyber Medical University, Peshawar, Pakistan

3 State Key Laboratory of Virology, College of Life Sciences, Wuhan University, Wuhan PR China

4 Department of Biotechnology, Faculty of Chemical and Life Sciences, Abdul Wali Khan University, Mardan, Pakistan

Correspondence: Abeer Kazmi, State Key Laboratory of Virology, College of Life Sciences, Wuhan University, Wuhan PR, China

Email: abeer_kazmi@yahoo.com patches covered by silver-coloured dead skin cells appearing as scales. About half of the patients experience the onset of symptoms below 25 years of age and mostly the females tend to be affected earlier than males ${ }^{4}$. Environmental factors such as infections, chemical agents, alcoholism, smoking, drugs as stress may provoke early events of the disease especially in those who are genetically vulnerable to psoriasis. Recent studies have shown that the early appearance of symptoms as compared to late onset involve genetic influence ${ }^{5}$ which include mutations in different genes such as, TNFRSF9, IL-28RA, RUNX3, IL23R, LCE3B/LCE3C, REL, B3GNT2, IFIH1, ERAP1, TNIP1, IL12B, EXOC2, HLA-C, TRAF3IP2, TNFAIP3 and several others which are thought to be causing factors for initiation of early onset of disease ${ }^{6}$. Vitamin $\mathrm{D}$ is a steroidal hormone chemically known as 1,25dihydroxycholecalciferol ${ }^{7}$. The parent compound of vitamin $\mathrm{D}$ is cholecalciferol and found in vitamin supplements and dairy products. Inside our body, vitamin $\mathrm{D}$ exists in two forms i.e. 25 hydroxy VD (25$\mathrm{OH}-\mathrm{VD})$ and 1, 25-dihydroxy VD $(1,25-[\mathrm{OH}] 2 \mathrm{VD})^{8}$.

Ann Jinnah Sindh Med Uni 2020; 6(2):37-43 
Both forms of VD are found in the blood and carrier proteins. About 10 to $15 \%$ are bound to albumin and 85 to $90 \%$ are bound to VD binding proteins $(\mathrm{VDBP})^{9,10}$. Normal serum vitamin D level is around $20-50 \mathrm{ng} / \mathrm{ml}$. Serum level less than $20 \mathrm{ng} / \mathrm{ml}$ is defined as vitamin $\mathrm{D}$ avitaminosis ${ }^{11}$.

Vitamin D produces its action in body through its receptor (VDR). The receptor is present on long arm chromosome 12q13-12q14 near the centromere consisting of 11 exons that together with the associated introns makeup nearly $75 \mathrm{~kb}$ of the DNA. The vitamin $D$ receptor (VDR) mediates the effects of the physically active form of vitamin D 1,25- dihydroxy vitamin D3 $(1,25(\mathrm{OH}) 2 \mathrm{D} 3)$. Upon activation, VDR ligand/receptor complex regulates the transcription level of target genes which are involved in Thelper (Th) cell improvement and Th cytokine profile change. The gene is involved in cellular growth, differentiation and activated inflammatory processes in keratinocytes. Vitamin D3 (calcitriol) through VDR gene regulates the functions of white blood cells like monocytes, T-cells, macrophages and dendritic cells. Based upon these mechanisms, the role of topical vitamin $\mathrm{D}$ formulations in curing psoriasis is still under investigation. These studies now give enough evidence for re-thinking vitamin $\mathrm{D}$ as possible candidate for the treatment of psoriasis ${ }^{12}$. The studies have shown that vitamin D (VD) and its active metabolite 1,25-dihydroxy VD has a role in the pathogenesis of psoriasis including genetic mutations in VDR. Most common Polymorphisms in VDR gene are $\mathrm{Cdx} 2$, Fok I, TaqI situated in exon 1,2 and 9 respectively while the BsmI and ApaI are in intron region between exon 7 and exon $8^{13,14}$. Therefore, in this study we analyzed and compared plasma levels of 25-(OH) D by ELISA in vitamin $\mathrm{D}$ deficient patients and normal healthy control samples along with VDR gene polymorphism (ApaI and TaqI) using allele specific polymerase chain reaction. This is the first report to show the role of VDR gene polymorphisms in the development of psoriasis in Pakistani population.

\section{METHODOLOGY}

The study was conducted on a total of 220 individuals. Out of these 220 individuals, 110 were the clinically diagnosed patients of psoriasis and 110 samples were taken from healthy control subjects. The cases included $48.18 \%$ females while in control group $49.10 \%$ were females. Similarly, the average ages of cases and controls were $57.36 \pm 6.25$ years and $58.71 \pm 8.39$ years, respectively.
Blood samples were taken from healthy individuals and psoriasis patients as per the inclusion criteria. Sampling was done at Khyber teaching Hospital (KTH) Peshawar, Lady Reading Hospital (LRH) Peshawar, Hayatabad Medical complex (HMC) Peshawar and experimental work was carried out in Institute of Basic Medical Sciences (IBMS), Khyber Medical University (KMU). Informed consents from the patients were taken. The study was approved from the Ethical Committee of the Khyber Medical University, Peshawar, Pakistan.

Clinically diagnosed psoriasis patients with complete medical history were included. There were no age and sex limitations. Patients with other skin diseases that mimic psoriasis were excluded from the study. Furthermore, patients not consenting and/or unwilling were also excluded from the study. Data of every sample was collected on a pre-designed pro forma. Apart from the demographic data, other information obtained from the patients included: name, age, gender, and ethnicity, duration of disease, family history of disease and history of other metabolic disorders.

Blood samples were collected in disposable syringes from every subject. A total of $3 \mathrm{ml}$ of blood was withdrawn from the antecubital vein of every subject under sterile conditions. The blood was divided into two portions. Two $\mathrm{ml}$ of the blood was transferred to labeled plain vacuum tube and the remaining $1 \mathrm{ml}$ to labeled ethylene diamine tetra-acetic acid (EDTA) tube for separation of cell pellet. Within half an hour, the blood in plain tube was centrifuged at $3000 \mathrm{rpm}$ for 10 minutes. A clear supernatant of serum was collected and transferred into a fresh Eppendorf tube and stored at $-20^{\circ} \mathrm{C}$ for biochemical analysis. While the blood in EDTA tubes, was stored at $4{ }^{\circ} \mathrm{C}$ for genotyping. ELISA Analysis: VD serum concentration was measured by an enzyme-linked immunosorbent assay (ELISA) kit (EQ 6411-9601 EUROIMMUN 25-OH VD ELISA kit manufactured by Medizinische labordiagnostika AG) Lot. No. E160916BH. The kit used solid phase competitive ELISA to assay the level of VD in human serum samples. The wells were precoated with monoclonal anti-25-OH VD antibodies. First the samples and calibrators/controls were diluted by adding $20 \mathrm{ul}$ of each with $0.5 \mathrm{ml}$ of working strength biotin. The solution was then incubated at room temperature for 10 minutes $\left(+18^{\mathrm{O}} \mathrm{C}\right.$ to $\left.+25^{\mathrm{O}} \mathrm{C}\right)$ and then pippeted into the microplate wells. 25-OH VD in the sample competed with biotin-labeled 25-OH VD enzyme conjugate for binding site. After washing completely, 3, 3', 5, 5'-tetramethylbenzidine (TMB) liquid substrate was added. The intensity of the colour produced was inversely proportional to the 
concentration of 25-OH VD in the samples. The reaction was terminated by the addition of a stop solution $(0.5$ M Sulfuric acid) and the colour change was measured at a wavelength of $450 \mathrm{~nm}$. All other steps of the assay were performed according to the manufacturer's instructions.

DNA Extraction: Before starting the DNA extraction procedure, all the plasticwares including tips, Eppendorf tubes, cell lysis buffer, nucleic lysis buffer and TE buffer were sterilized in auto clave. Chloroform and ethanol were pre-chilled at $-20^{\circ} \mathrm{C}$. Total $0.6 \mathrm{ml}$ of blood was dissolved in $1.2 \mathrm{ml}$ of cell lysis buffer in 2 $\mathrm{ml}$ pre-sterilized Eppendorf tube. The solution was mixed thoroughly and centrifuged at $7000 \mathrm{rpm}$ for five minutes. The supernatant was discarded carefully, and the pellet was washed 2-3 times with cell lysis buffer up to clarity. The set speed was $5000 \mathrm{rpm}$ after first washing. The Eppendorf tube was kept for 2-3 minutes until the pellet was dried. To the pellet, $0.5 \mathrm{ml}$ nucleus lysis buffer was added and after dissolving the pellet by pipetting, $0.15 \mathrm{ml}$ of saturated $\mathrm{NaCl}$ and $0.7 \mathrm{ml}$ of pre-chilled chloroform was added. The Eppendorf tube was centrifuged at $7000 \mathrm{xg}$ for three minutes. The two visible layers were achieved after centrifugation. The supernatant $(0.5 \mathrm{ml})$ was carefully? $12000 \mathrm{xg}$ for 2 minutes to precipitate the DNA. The supernatant was carefully discarded, and DNA was washed with $70 \%$ ethanol and centrifuged at maximum speed (14000xg) for 10 minutes. The supernatant was removed, and the tubes kept for 10 minutes at room temperature. The DNA was re-suspended in $0.1 \mathrm{ml} \mathrm{TE}$ buffer and was kept at $-20^{\circ} \mathrm{C}$.

PCR amplification: PCR assay was done for each DNA sample in a final reaction volume of $10 \mu \mathrm{l}$. Specific PCR primers were designed. The Control forward primers used for VDR-ApaI genotyping were 5'-CCA AAC ACT TCG AGC ACA AGG-3' and Control Reverse 5'-AGA GCA GAG TTC CAA GCAGAG G-3' with product size 592 bp. The allele specific reverse primer 5'- GGT GGG ATT GAG CAG TGA AGT-3' and reverse 5'-GGT GGG ATT GAG CAG TGA TGG-3' with product size 318 bp were respectively. Similarly, the control forward and reverse primers for VDR-TaqI genotyping were 5'-GCC AAA CAC TTC GGC AAG-3' and 5'-CGG TCC TGA ATG GCC ACA-3' respectively with product size of 592 bp. The allele specific forward and reverse primers were 5'-CAG AGC ATG GAC AGG GAG CAAG-3' and 5'-CAC ACTG CAG ACG TAC ATCC-3' respectively with PCR product size of $340 \mathrm{bp}$. The primers sequences are shown in Table 1 for allelic discrimination of both ApaI and TaqI polymorphisms in our study samples. The PCR product sizes are shown in Table 2 and the gel electrophoresis results are shown in Fig. 1 and Fig. 2. For each sample, four PCR tubes were labeled i.e. two tubes for VDR-TaqI and two tubes for VDR-ApaI PCR assays. The tubes were labelled as ' $\mathrm{C}$ ' for $\mathrm{C}$ allele, ' $\mathrm{T}$ ' for $\mathrm{T}$ allele for $\mathrm{VDR}$ TaqI PCR assay and 'A' for A allele, 'C' for $\mathrm{C}$ allele for VDR-ApaI. Final reaction volume was prepared by taking $7 \mu \mathrm{l}$ of deionized water, $0.8 \mu \mathrm{l}$ of $10 \mathrm{x}$ PCR buffer, $0.3 \mu \mathrm{l}$ of $\mathrm{MgCl} 2,0.5 \mu \mathrm{l}$ of $10 \mathrm{mM}$ dNTPs, 0.5 $\mu \mathrm{l}$ of template DNA, $0.3 \mu \mathrm{l}$ of control primers, $0.3 \mu \mathrm{l}$ of allele specific primers ( $\mathrm{C}$ and $\mathrm{T}$ ) in one PCR tube and $0.3 \mu \mathrm{l}$ of allele specific primers (A and $\mathrm{C}$ ) in the other PCR tube. The PCR tubes were vortexed for 510 seconds and then were run in a PCR thermal cycler (Multigene Optimax). The PCR conditions are mentioned in Table 2 and were as follows: denaturation at $94^{\circ} \mathrm{C}$ for 5 minutes, followed by 30 cycles of PCR: denaturation at $95^{\circ} \mathrm{C}$ for one minute, annealing at $64^{\circ} \mathrm{C}$ for 30 seconds, polymerization at $72^{\circ} \mathrm{C}$ for one minute and proof reading at $72^{\circ} \mathrm{C}$ for five minutes.

Stock Solutions Preparation: Total 46.1 gm of EDTA was dissolved in about $800 \mathrm{ml}$ of distilled water and placed on magnetic stirrer. The $\mathrm{pH}$ was adjusted with sodium hydroxide $(\mathrm{NaOH})$ to 7.5. After $\mathrm{pH}$ adjustment, sufficient quantity of distilled water was added to make up the volume $1000 \mathrm{ml} ; 121.14 \mathrm{gm}$ of ultra-pure tris was dissolved in about $800 \mathrm{ml}$ of distilled water and placed on magnetic stirrer. The $\mathrm{pH}$ was adjusted with hydrochloric acid $(\mathrm{HCl})$ to 8.0. After $\mathrm{pH}$ adjustment, sufficient quantity of water was added to make up the volume $1000 \mathrm{ml}$. Then $12 \mathrm{mM}$ Tris-HCl, $350 \mathrm{mM}$ Sucrose, $6 \mathrm{mM} \mathrm{MgCl} 2$ and $1 \%$ Triton X 100 were dissolved in $700 \mathrm{ml}$ distilled water. After complete dissolution, sufficient distilled water was added to make up the volume $1000 \mathrm{ml}$.

Next, 12 mM Tris-HCL, 15 mM Ammonium Acetate $1.5 \mathrm{mM}$ EDTA and 2\% SDS solution were dissolved in $700 \mathrm{ml}$ distilled water and after complete dissolution, enough water was added to make up the volume 1000 ml. $\mathrm{NaCl} 59$ gm was dissolved in $150 \mathrm{ml}$ of distilled water and after complete dissolution; sufficient water was added to make up the volume $200 \mathrm{ml} ; 5 \mathrm{ml} 1 \mathrm{M}$ Tris- $\mathrm{HCl}$ solution and $2 \mathrm{ml} 0.5 \mathrm{M}$ EDTA solutions were dissolved in $1000 \mathrm{ml}$ of distilled water.

Statistical analysis: Statistical Package for the Social Sciences (SPSS) v23.00 software was used to determine the genetic association between psoriasis and VDR polymorphism. Chi-square test was performed to determine the association between alleles and genotypes while allele and genotype frequencies were assessed under HardyWeinberg Equilibrium (HWE). Odds Ratio (OR) was calculated with $95 \%$ Confidence Interval (CI). 


\section{RESULTS}

The association study between VDR SNPs (apaI and TaqI) and psoriasis was conducted in 110 psoriasis cases and 110 healthy controls. The clinical demographic data of study samples is mentioned in Fig. 3. The average Body Mass Index (BMI) of both cases and controls was $25.79 \pm 3.97$ and $30.767 \pm 6.59$, respectively. Similarly, initial serum vitamin D levels were calculated in both cases and healthy control samples were $13.5 \pm 5.34$ and $29.02 \pm 17.65$, respectively. The results were statistically analyzed by using chisquare $\left(\mathrm{x}^{2}\right)$ test as shown in Table 3 , which showed significant association between the VDR SNPs (ApaI and TaqI) and psoriasis $(\mathrm{p}=0.0162$ and 0.0019 respectively). To check either this significant association is a risk factor for the onset of disease, we calculated the odds ratio between the cases and controls. The results are mentioned in Table 4 which showed that although our study SNPs were significantly associated with psoriasis, but they are not a risk factor for onset of psoriasis. The odds ratios also showed that these polymorphisms are risk factors for development of psoriasis (Odds ratios of 2.29 and 2.96). Similarly, the serum levels of vitamin D in both cases and controls were statistically analyzed through chi-square test. According to our results, the low levels of serum vitamin $\mathrm{D}$ in cases $(13.5 \pm 5.34 \mathrm{ng} / \mathrm{ml})$ as compared to controls $(29.02 \pm 17.65 \mathrm{ng} / \mathrm{ml})$ with $\mathrm{p}$-value less than $0.005(<0.0001)$ shows a strong association with psoriatic plaques. The results are summarized in Table 3. Finally, the levels of vitamin D in both cases and controls were statistically compared with VDR SNPs i.e. ApaI and TaqI. The results showed that these VDR mutations are risk factors for early onset of psoriasis symptoms in local population of Peshawar, KPK, Pakistan and nearby areas (Table 5).

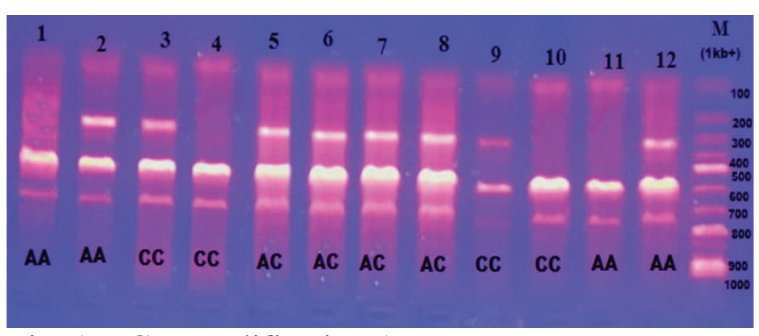

Fig. 1: PCR amplification ApaI

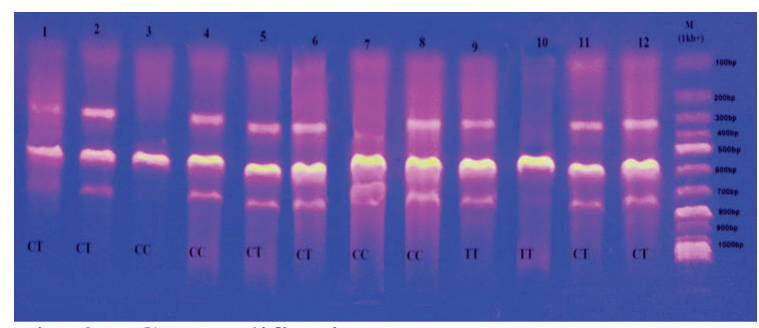

Fig. 2: PCR amplification TaqI

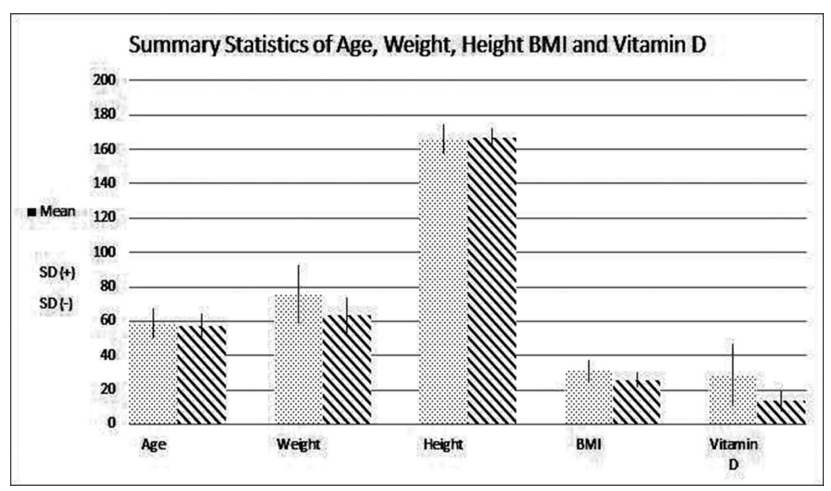

Fig. 3: Demographic Parameters of Controls and Cases

Table 1: ASPCR Primers with specific Sequences

\begin{tabular}{|c|c|c|c|}
\hline \multicolumn{2}{|c|}{ Primers Type } & Primers Sequence & PCR Product size \\
\hline \multirow[t]{2}{*}{ Apa I } & Controls & $\begin{array}{l}\text { Forward: } 5^{\circ} \text { CCA AAC ACT TCG AGC ACA AGG } 3^{\circ} \\
\text { Reverse: } 5^{\circ} \text { AGA GCA GAG TTC CAA GCAGAG G } 3^{\circ}\end{array}$ & 592 bp \\
\hline & Allele Specific & $\begin{array}{l}\text { Reverse: } 5^{\circ} \text { GGT GGG ATT GAG CAG TGA AGT } 3^{\circ} \\
\text { Reverse: } 5^{\circ} \text { GGT GGG ATT GAG CAG TGA TGG } 3^{\circ}\end{array}$ & $318 \mathrm{bp}$ \\
\hline \multirow[t]{2}{*}{ Taq I } & Controls & $\begin{array}{l}\text { Forward: } 5^{\circ} \mathrm{GCC} \text { AAA CAC TTC GGC AAG } 3^{\circ} \\
\text { Reverse: } 5^{\circ} \mathrm{CGG} \text { TCC TGA ATG GCC ACA } 3^{\circ}\end{array}$ & 592 bp \\
\hline & Allele Specific & $\begin{array}{l}\text { Forward: } 5^{\circ} \mathrm{CAG} \text { AGC ATG GAC AGG GAG CAAG } 3^{\circ} \\
\text { Reverse: } 5^{\circ} \mathrm{CAC} \text { ACTG CAG ACG TAC ATCC } 3^{\circ}\end{array}$ & $340 \mathrm{bp}$ \\
\hline
\end{tabular}


Vitamin D and its receptor gene single nucleotide polymorphism

Table 2: PCR Amplification Profile

\begin{tabular}{|l|c|c|c|}
\hline & Temperature $\left({ }^{\mathrm{O}} \mathrm{C}\right)$ & Duration (minutes) & No of Cycles \\
\hline Activation & 95 & 5 & 1 \\
\hline Denaturation & 95 & 1.0 & \multirow{2}{*}{30} \\
\cline { 1 - 3 } Annealing & 64 & 0.5 & \\
\hline Extension & 72 & 1.0 & 1 \\
\hline Final Extension & 72 & 10.0 & Hold \\
\hline Soak & 4 & 8 & \\
\hline
\end{tabular}

Table 3: Association of TaqI with

\begin{tabular}{|c|c|c|c|}
\hline \multicolumn{4}{|c|}{ Psoriasis } \\
\hline Genotypes & Controls (n) & Disease (n) & p-value \\
\hline $\mathrm{CC}$ & 48 & 18 & \multirow{3}{*}{0.0019} \\
\hline TT & 17 & 42 & \\
\hline $\mathrm{CT}$ & 45 & 50 & \\
\hline \multicolumn{4}{|c|}{ Apa-I with Psoriasis } \\
\hline Genotypes & Controls (n) & Disease $(n)$ & $\mathrm{p}$-value \\
\hline $\mathrm{AA}$ & 42.72 & 21.82 & \multirow{3}{*}{0.0016} \\
\hline $\mathrm{CC}$ & 19.10 & 34.55 & \\
\hline $\mathrm{AC}$ & 38.12 & 43.64 & \\
\hline \multicolumn{4}{|c|}{ Vitamin D with Psoriasis } \\
\hline Group & Number & $\begin{array}{c}\text { Vitamin D } \\
\mathrm{ng} / \mathrm{ml}\end{array}$ & $\mathrm{p}$-value \\
\hline Cases & 110 & $13.5 \pm 5.34$ & \multirow{2}{*}{$<0.0001$} \\
\hline Control & 110 & $29.02 \pm 17.65$ & \\
\hline
\end{tabular}

Table 4: Odds ratio CC vs CT (TaqI) and AA vs AC (ApaI)

\begin{tabular}{|c|c|c|c|c|c|}
\hline \multicolumn{6}{|c|}{$\mathrm{CC}$ vs CT } \\
\hline Genotype & Cases & Controls & CI 95\% & Odds Ratio & p-value \\
\hline $\mathrm{CC}$ & 18 & 48 & \multirow[b]{2}{*}{1.508 to 5.743} & \multirow[b]{2}{*}{2.963} & \multirow[b]{2}{*}{0.0019} \\
\hline $\mathrm{CT}$ & 50 & 45 & & & \\
\hline \multicolumn{6}{|c|}{ AA vs AC } \\
\hline Genotype & Cases & Controls & CI $95 \%$ & Odds Ratio & p-value \\
\hline AA & 24 & 47 & \multirow[b]{2}{*}{1.22 to 4.246} & \multirow[b]{2}{*}{2.293} & \multirow[b]{2}{*}{0.0162} \\
\hline $\mathrm{AC}$ & 48 & 41 & & & \\
\hline
\end{tabular}

Table 5: Allele frequency of VDR Polymorphisms between cases and controls

\begin{tabular}{|c|c|c|c|c|c|c|c|c|}
\hline \multirow[t]{2}{*}{$\begin{array}{l}\text { VDR } \\
\text { Loci }\end{array}$} & \multirow[t]{2}{*}{ SNP } & \multirow[t]{2}{*}{ Genotype } & \multirow[t]{2}{*}{$\begin{array}{l}\text { Cases \% } \\
(\mathrm{n}=110)\end{array}$} & \multirow[t]{2}{*}{$\begin{array}{c}\text { Controls\% } \\
(\mathrm{n}=110)\end{array}$} & \multicolumn{2}{|c|}{$\begin{array}{c}\text { Vitamin D } \\
\text { Level (ng/ml) }\end{array}$} & \multirow[t]{2}{*}{ OR } & \multirow[t]{2}{*}{ p-value } \\
\hline & & & & & Cases & Controls & & \\
\hline \multirow{3}{*}{ Apa 1} & \multirow{3}{*}{$\mathrm{A}>\mathrm{C}$} & AA & 21.18 & 42.7 & \multirow{6}{*}{13.5} & \multirow{6}{*}{29.02} & \multirow{3}{*}{2.29} & \multirow{3}{*}{0.0162} \\
\hline & & $\mathrm{CC}$ & 34.5 & 19 & & & & \\
\hline & & $\mathrm{AC}$ & 43.6 & 37.3 & & & & \\
\hline \multirow{3}{*}{ Taq 1} & \multirow{3}{*}{$\mathrm{C}>\mathrm{T}$} & $\mathrm{CC}$ & 16.36 & 43.6 & & & \multirow{3}{*}{2.96} & \multirow{3}{*}{0.0019} \\
\hline & & $\mathrm{TT}$ & 38.18 & 15.45 & & & & \\
\hline & & $\mathrm{CT}$ & 45.45 & 40.9 & & & & \\
\hline
\end{tabular}




\section{DISCUSSION}

Recent advancements in genetics have shown a relationship between psoriasis and gene mutations. Russel et al first time reported the association between HLA-B13 (Human Leukocyte Antigen serotype) and psoriasis ${ }^{15}$. Besides common type of psoriasis, genetic involvement in a rare type of psoriasis known as "Pustular psoriasis" has shown mutation in IL36RN ${ }^{16}$. This allele encodes IL36 receptor antagonist protein which reduces cytokines production. Mutation in IL36RN allele results in synthesis of abnormal protein and increase production interleukins (IL-8) from keratinocytes ${ }^{17}$. The type-2 psoriasis is a type whose genetic cause is not very much clear which shows the diversity of genetic variations associated with different types of psoriasis ${ }^{6}$. Previous study by Keren et al reported the role of vitamin D and its analogues in defensive mechanisms of skin and suggested the effective use of vitamin D in treatment of psoriasis $^{18}$. Vitamin D influences the homeostasis of skin through its receptor i.e. vitamin $\mathrm{D}$ receptor.

The association between psoriasis and vitamin D polymorphisms and blood levels is not well understood as no such study had been performed previously. But vitamin D levels and VDR gene polymorphisms are associated with other autoimmune diseases like rheumatoid arthritis and multiple sclerosis. Hence, one can rationalize the possible association between psoriasis and vitamin D serum concentrations and VDR gene polymorphisms. To find possible association between psoriasis and VDR gene polymorphisms, we designed a case-control study for this purpose. The current study elucidates the role of VD and VDR gene polymorphism and showed significant difference between VD levels and genotypes of disease and control group. In our study, a total of 220 individuals of same age group were included. Out of 220, 110 were psoriatic patients and 110 were healthy controls. Level of vitamin D was analyzed for both case and control groups using commercially available kits. The levels of vitamin D were normal in control group $(29.02 \pm 17.65 \mathrm{ng} / \mathrm{ml})$ while levels were below than normal in diseased patients $(13.5 \pm 5.34 \mathrm{ng} / \mathrm{ml})$. The purpose of our study was to determine possible association between VDR gene polymorphism (TaqI and ApaI) and psoriasis. Genetic polymorphisms were checked by analyzing the restriction pattern of the polymerase chain reaction (PCR) products. The results were analyzed through chi-square analysis which showed a significant association between both TaqI and ApaI polymorphisms with psoriasis with a mean p-value of $0.009(0.0019$ and 0.0162 ). The odds ratios (95\% confidence interval) for psoriasis of CC vs CT (TaqI) and AA vs AC (ApaI) were 2.963 (1.508-5.743) and 2.293 (1.22-4.246), respectively. The odds ratios show that VDR genes polymorphisms are risk factors for the onset of psoriasis. Similarly, vitamin D levels in psoriatic cases and healthy controls were analyzed through chi-square which also showed significant association between low vitamin D level and psoriasis disease ( $\mathrm{p}$-value < 0.005). Hence, through our study, we have shown that VDR gene polymorphisms (TaqI and ApaI) are significantly associated with the onset and progression of psoriasis. Furthermore, levels of vitamin D are very low in our case group that further complicates the psoriasis profile of cases and may be a risk factor for development of psoriasis.

\section{CONCLUSION}

Study concludes that VDR gene polymorphisms (TaqI and ApaI) were associated with the development of psoriasis. Vitamin D receptor SNP was associated with increased risk of psoriasis. Vitamin D deficiency may be a modifiable risk factor for developing psoriasis.

Authors' contribution: M.I.S, M.S, S.S, and M.A, conceptualized study design, collected, analyzed and interpreted data. M.A.S, and A.K interpreted data, prepared manuscript and did proof reading.

\section{References}

1. Feingold KR, Grunfeld C. Psoriasis: it's more than just the skin. J Lipid Res. 2012;53(8):1427-9. doi: 10. 1194/ jlr.E029330

2. McKenna K, R Stern MD. The outcomes movement and new measures of the severity of psoriasis. J Am Academy Dermatol. 1996;34(3):534-8. https:// doi.org/10.1016/S0190-9622(96)90469-7.

3. Baurecht H, Hotze M, Brand S, Büning C, Cormican $\mathrm{P}$, Corvin A, et al. Genome-wide comparative analysis of atopic dermatitis and psoriasis gives insight into opposing genetic mechanisms. Am J Hum Genet. 2015;96(1):104-20. doi: 10.1016/j.ajhg.2014.12.004.

4. Swanbeck G, Inerot A, Martinsson T, Wahlström J, Enerbäck C, Enlund F, et al. Age at onset and different types of psoriasis. Br J Dermatol. 1995;133(5):768-73. doi: $10.1111 / \mathrm{j} .1365-2133.1995$.

5. Swanbeck G, Inerot A, Martinsson T, Enerbäck C, Enlund F, Samuelsson L, et al. Genetic counselling in psoriasis: empirical data on psoriasis among first-degree relatives of 3095 psoriatic probands. Br J Dermatol. 1997;137(6):939-42.

6. Mahil SK, Capon F, Barker JN. Genetics of psoriasis. Dermatol Clin. 2015;33(1):1-11. DOI: 10.1016/j.det.2014.09.001 
7. Hollis BW, Wagner CL. Assessment of dietary vitamin $\mathrm{D}$ requirements during pregnancy and lactation. Am J Clin Nutr. 2004;79(5):717-26. doi: 10.1093/ ajen/ 79. 5.717 .

8. Hollis BW, Wagner CL, Drezner MK, Binkley NC. Circulating vitamin D 3 and 25-hydroxyvitamin D in humans: an important tool to define adequate nutritional vitamin D status. J Steroid Biochem Mol Biol. 2007;103(3):631-4. doi: 10.1016/j.jsbmb.2006.12.066.

9. Bikle D, Siiteri P, Ryzen E, Haddad J, Gee E. Serum protein binding of 1, 25-dihydroxyvitamin D: a reevaluation by direct measurement of free metabolite levels. J Clin Endocrinol Metab. 1985;61(5):969-75. doi: 10.1210/jcem-61-5-969.

10. Bikle D, Gee E, Halloran B, Haddad JG. Free 1, 25dihydroxyvitamin $\mathrm{D}$ levels in serum from normal subjects, pregnant subjects, and subjects with liver disease. J Clin Invest. 1984;74(6):1966. doi: 10.1172/ JCI111617.

11. Hashemipour S, Larijani B, Adibi H, Javadi E, Sedaghat M, Pajouhi M, et al. Vitamin D deficiency and causative factors in the population of Tehran. BMC Public Health. 2004;4(1):38. doi: 10.1186/1471-2458-4-38.

12. Fu LW, Vender R. Systemic role for vitamin D in the treatment of psoriasis and metabolic syndrome. Dermatol Res Pract. 2011;2011:276079. doi: 10.1155/2011/ 276079.
13. Taymans SE, Pack S, Pak E, Orban Z, Barsony J, Zhuang Z, et al. The Human Vitamin D Receptor Gene (VDR) Is Localized to Region 12cen-q12 by Fluorescent In Situ Hybridization and Radiation Hybrid Mapping: Genetic and Physical VDR Map. J Bone Miner Res. 1999;14(7):1163-6. doi: 10.1359/jbmr.1999.14.7.1163.

14. Miyamoto K-i, Kesterson RA, Yamamoto H, Taketani Y, Nishiwaki E, Tatsumi S, et al. Structural organization of the human vitamin D receptor chromosomal gene and its promoter. Mol Endocrinol.1997;11(8):1165-79. doi:10.1210/mend.11.8.9951.

15. Nair RP, Stuart PE, Nistor I, Hiremagalore R, Chia NV, Jenisch $\mathrm{S}$, et al. Sequence and haplotype analysis supports HLA-C as the psoriasis susceptibility 1 gene. Am J Hum Genet. 2006;78(5):827-51. doi: 10.1086/ 503821 .

16. Marrakchi S, Guigue P, Renshaw BR, Puel A, Pei XY, Fraitag S, et al. Interleukin-36-receptor antagonist deficiency and generalized pustular psoriasis. N Engl J Med. 2011;365(7):620-8. doi:10.1056/NEJMoa 1013068 .

17. Setta-Kaffetzi N, Navarini AA, Patel VM, Pullabhatla V, Pink AE, Choon S-E, et al. Rare pathogenic variants in IL36RN underlie a spectrum of psoriasis-associated pustular phenotypes. J Invest Dermatol. 2013;133(5): 1366-9. doi: 10.1038/jid.2012.490.

18. Lowe KE, Norman AW. Vitamin D and psoriasis. Nutr Rev.1992;50(5):138-42.doi: 10.1111/j.17534887.1992.tb01305.x. 